\title{
The morphological diversity of Garra barreimiae [Teleostei: Cyprinidae]
}

\author{
Arthur Pichler (D) - Harald Ahnelt - Sandra Kirchner - Helmut Sattmann • \\ Elisabeth Haring • Stephan Handschuh • Jörg Freyhof • Reginald Victor • \\ Luise Kruckenhauser
}

Received: 15 September 2017 / Accepted: 2 April 2018/Published online: 14 April 2018

(C) The Author(s) 2018

\begin{abstract}
Garra barreimiae (Fowler and Steinitz, Bull Res Counc Isr 5B:262-289, 1956) is a freshwater fish that lives throughout the Hajar Mountains of Oman and the United Arab Emirates. Previously, four different genetic clades (West clade, Central Clade, North clade and East clade) have been identified within this species. This study observes morphological differences between these clades using morphometrics and meristics as well as micro CT imaging, further strengthening the assumption that the taxon of $G$. barreimiae should be restricted to one of the genetic clades detected. Although many morphometric and meristic characteristics are highly variable within the clades, the West clade fits the original description of G. barreimiae and is distinguishable by its higher number of fifteen to seventeen gill rakers on the lower limb of the first gill arch (compared to the other clades with ten to fourteen gill rakers), its seven
\end{abstract}

\footnotetext{
A. Pichler $(\bowtie) \cdot$ S. Kirchner $\cdot$ E. Haring $\cdot$ L. Kruckenhauser Central Research Laboratories, Laboratory of Molecular Systematics, Museum of Natural History Vienna, Burgring 7, 1010 Vienna, Austria

e-mail: arthur.pichler@univie.ac.at
}

A. Pichler $\cdot$ S. Kirchner $\cdot$ E. Haring

Department of Integrative Zoology, University of Vienna,

Althanstraße 14, 1090 Vienna, Austria

H. Ahnelt

Department of Theoretical Biology, University of Vienna, Althanstraße 14, 1090 Vienna, Austria

H. Ahnelt

1st Zoological Department, Museum of Natural History Vienna,

Burgring 7, 1010 Vienna, Austria branched pelvic fin rays (in contrary to the other clades with eight branched pelvic fin rays) and its number of vertebrae, with typically nineteen precaudal and one intermediate vertebrae, compared to eighteen precaudal and two intermediate vertebrae in the Central and North clade and seventeen precaudal and two intermediate vertebrae in the East clade.

Keywords Garra barreimiae · Labeonini · Micro CT . Morphometrics · Oman · Hajar Mountains

\section{Introduction}

Labeonine cyprinids of the genus Garra (Hamilton, 1822) are widespread in tropical and subtropical Asia, Africa and the Middle East (Menon 1964; Yang and

H. Sattmann

3rd Zoological Department, Museum of Natural History Vienna, Burgring 7, 1010 Vienna, Austria

S. Handschuh

VetImaging, VetCore Facility for Research, University of Veterinary Medicine Vienna, Veterinärplatz 1, 1210 Vienna, Austria

J. Freyhof

Leibniz-Institute of Freshwater Ecology and Inland Fisheries (IGB), Müggelseedamm 310, 12587 Berlin, Germany

R. Victor

Department of Biology, Sultan Qaboos University, Al Khoudh, 123 Muscat, Oman 
Mayden 2010). Following species of Garra occur on the Arabian Peninsula: Garra buettikeri (Krupp 1983), Garra dunsirei (Banister 1987), Garra lautior (Banister 1987), Garra longipinnis (Banister and Clarke 1977), Garra mamshuqa (Krupp 1983), Garra sahilia (Krupp 1983), Garra smarti (Krupp and Budd 2009), Garra tibanica (Trewavas, 1941) and Garra barreimiae (Fowler and Steinitz 1956) (Freyhof et al. 2015). Only recently Garra barreimiae gallagheri was raised to species level and Garra sindhi has been described from the Dhofar region in Oman (Lyon et al. 2016). New Garra species have also been described from areas adjacent to the Arabian Peninsula, including Garra jordanica (Hamidan et al. 2014), Garra mondica (Sayyadzadeh et al. 2015), Garra lorestanensis (Mousavi-Sabet and Eagderi 2016), Garra tashanensis (Mousavi-Sabet et al. 2016) and Garra amirhosseini (Esmaeili et al. 2016), demonstrating, that more undescribed species might be found in the area. This is especially true for the Arabian Peninsula, where most freshwater fish now live in isolated refuges. These fish live in very dry and often unstable habitats only inhabited by a restricted number of fish species which have adapted to massive changes in water level, temperature and therefore oxygen content as well as availability of food (Krupp 1988).

Garra barreimiae is one of these species having a very fragmented distribution area with many small and isolated populations. The species is widespread in Northern Oman and the United Arab Emirates (Banister and Clarke 1977; Krupp 1983; Freyhof et al. 2015). Fowler and Steinitz (1956) described G. barreimiae from Buraimi (also Al Buraimi, Baraimi, Barreimi) in Oman. Later, two additional subspecies were described: Garra barreimiae shawkahensis (Banister and Clarke 1977) from the United Arab Emirates and Garra barreimiae gallagheri (Krupp 1988) from Wadi Bani Khalid in Oman. In 1980 Dunsire and Gallagher reported a subterranean population of G. barreimiae from the Al Hoota Cave close to Nizwa (Banister 1984). This troglomorphic population seems to be of recent origin less than one million years ago (Kruckenhauser et al. 2011), however occasional gene flow between the cave population and the surface population seems to take place (Kirchner et al. 2017). Although many populations of G. barreimiae are very isolated from each other and inhabit different drainage systems around the Hajar Mountains (Kruckenhauser et al. 2011; Freyhof et al. 2015), in former times during intermittent pluvial intervals, the river network was much denser, so populations might have been more connected. Kruckenhauser et al. (2011) were the first to use molecular genetic methods to assess genetic differentiation among populations of $G$. barreimiae. On the basis of DNA sequences of the mitochondrial control region $(\mathrm{mt} \mathrm{CR})$ two well differentiated clades were found, one in the surroundings of the Al Hoota cave, with a separated subclade which consists of individuals from Wadi Bani Khalid (= G. gallagheri), and one in the northeast of the Hajar Mountains. Subsequent genetic analysis (Kirchner et al. 2017) distinguished at least four different clades with p-distances between $6 \%$ and $10 \%$, as measured in a section of the $\mathrm{mt}$ cytochrome $c$ oxidase subunit 1 gene (COI). These clades are geographically separated but their distribution does not reflect the distribution of the subspecies previously described. Furthermore, including $G$. rufa into the tree revealed that $G$. barreimiae in the sense of Kruckenhauser et al. (2011) might not be monophyletic. With the newly discovered and strikingly different mt clades, which may indicate cryptic species, the morphological characteristics of these clades ought to be examined.

Water extraction in Oman has increased drastically in the last three decades (Al-Rawahi et al. 2014) which poses a threat to isolated fish populations. G. barreimiae is widely distributed throughout the Northern Oman, but since many populations are isolated and potentially vulnerable to water extraction (Freyhof et al. 2015) it appears even more urgent to study potentially cryptic species within G. barreimiae.

This study is part of a broader phylogenetic analysis of the G. barreimiae complex and aims to reveal whether morphological differences can be found between previously determined genetic clades using morphometrics and meristics as well as micro CT imaging, which is used for the first time to compare the osteology within G. barreimiae.

\section{Material and methods}

Eighty-seven specimens of $G$. barreimiae, collected at 20 localities in Oman (Fig. 1; Table 1), were included in the morphological analysis. Specimens were captured with fishing nets, immediately anesthetized with clove oil and fixed in $80 \%$ ethanol. The individuals, which are part of the collection of the Natural History Museum Vienna (NHMV), represent four mitochondrial (mt) 
Fig. 1 Sampling sites of specimens used in morphological analysis and sites of original descriptions across the Al Hajar Mountains, Oman. West clade: blue; Central clade: red; North clade: green; East clade: grey; A: Buraimi, type locality of Garra barreimiae (Fowler and Steinitz 1956); B: Wadi Sahtan; assigned to Garra barreimiae barreimiae by Banister and Clarke (1977); C: Wadi Shawkah, type locality of Garra barreimiae shawkahensis (Banister and Clarke 1977); D: Wadi Bani Khalid; type locality of Garra gallagheri (Krupp 1988), not included in this study. Scale bar: $50 \mathrm{~km}$

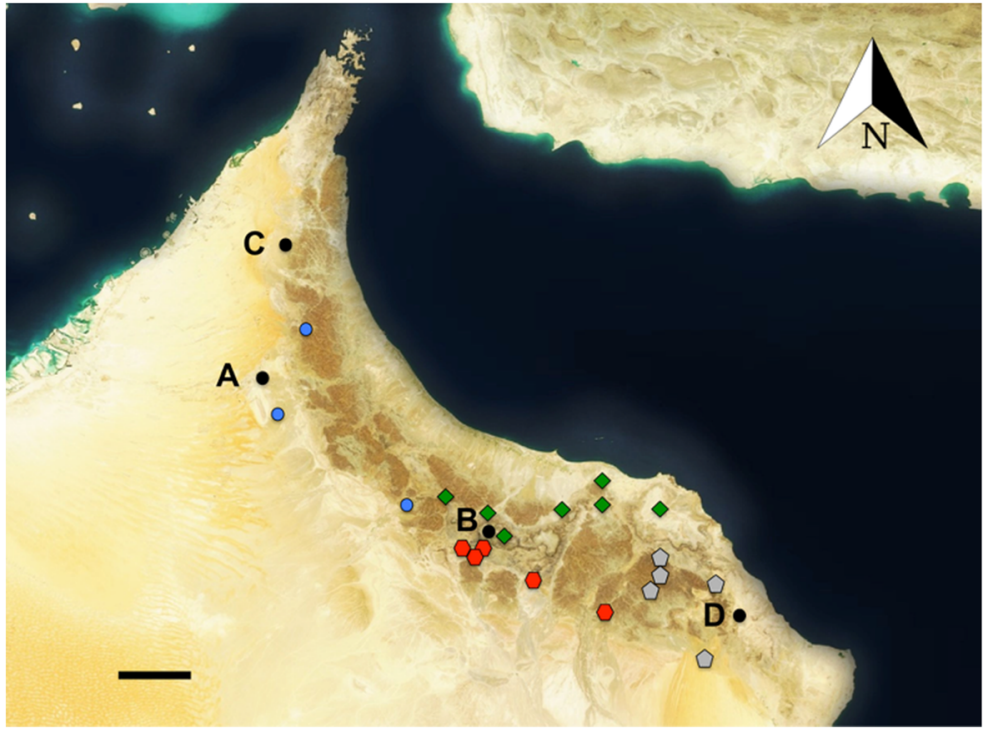

clades (Kruckenhauser et al. 2011; Kirchner et al. 2017): West clade ( $n=19)$, Central clade $(n=25)$, North clade $(\mathrm{n}=19)$ and East clade $(n=24)$.

Table 1 Sampling sites for each clade with corresponding coordinates as decimal degrees [longitude, latitude] and number of morphologically examined specimens (n)

\begin{tabular}{llll}
\hline Clade & Sampling Site & Coordinates & $\mathrm{n}$ \\
\hline West clade & Al Hayyal & {$[23.43,56.74]$} & 7 \\
& Al Juwayf & {$[24.54,56.10]$} & 7 \\
Central clade & Hafeet & {$[23.99,55.84]$} & 5 \\
& Al Hamra & {$[23.11,57.28]$} & 1 \\
& Birkat al Mawz & {$[22.92,57.66]$} & 2 \\
& Lizq & {$[22.71,58.17]$} & 4 \\
& Misfat al Abriyeen & {$[23.14,57.31]$} & 10 \\
& Wadi an Nakhar & {$[23.17,57.20]$} & 8 \\
North clade & Wadi al Mayh & {$[23.40,58.52]$} & 4 \\
& Wadi Hammam & {$[23.37,57.82]$} & 4 \\
& Wadi Hat & {$[23.18,57.41]$} & 1 \\
& Wadi Khawd & {$[23.57,58.11]$} & 5 \\
& Wadi Mansah & {$[23.40,58.11]$} & 1 \\
& Wadi Sahtan & {$[23.38,57.30]$} & 2 \\
& Wadi Shkar & {$[23.45,57.06]$} & 2 \\
& Al Hajir & {$[22.98,58.50]$} & 7 \\
& Wadi Dayn & {$[22.89,58.42]$} & 2 \\
& Wadi Khabbah 1 & {$[22.91,58.87]$} & 7 \\
Wadi Khabbah 2 & {$[23.11,58.50]$} & 6 \\
& Mintirib & {$[22.43,58.79]$} & 2 \\
\hline
\end{tabular}

Twenty-five measurements (Table 2) were taken at least two times with a digital calliper from point to point to the nearest $0.1 \mathrm{~mm}$. Methods for counts and measurements largely followed Armbruster (2012). Due to the condition of preserved specimens (crooked fixation, mutilated fins, cuts in the ventral region) not all measurements and counts could be taken from all specimens. Measurements were described in percent of standard length unless stated otherwise. Measurements were tested for normality (Shapiro Wilk's test) and equality of variance (Levene's Test) before conducting One-way ANOVA. Kruskal-Wallis test was used to test for significant differences in non-parametric data. Tukey's honest significant difference test was used as post-hoc test after ANOVA. Principal component analysis (PCA) and linear discriminant analysis (LDA) were conducted using the following characters, which were chosen because of their parametric nature and significant differences between the mt clades: anal fin - caudal fin, head length, head width (in \% of head length), internostral distance (in \% of head length), orbit diameter (in \% of head length), snout length (in \% of head length), pectoral fin - pelvic fin, pelvic fin - anal fin and prepelvic length. All tests and analyses were conducted using Past3 (Hammer et al. 2001). Violin plots were constructed using Rstudio version 1.0.136 and the R package ggplot2 (R Development Core Team 2015; Wickham 2009).

Meristic counts of gill rakers of the lower limb of the first gill arch (ceratobranchial), simple and branched dorsal fin rays, anal fin rays, pectoral fin rays, pelvic fin rays, caudal fin rays as well as lateral line scales and 
Table 2 Morphometric data of the four mitochondrial (mt) clades

\begin{tabular}{|c|c|c|c|c|c|c|c|c|c|c|c|c|c|c|c|c|}
\hline & \multicolumn{4}{|c|}{ West clade } & \multicolumn{4}{|c|}{ Central clade } & \multicolumn{4}{|c|}{ North clade } & \multicolumn{4}{|c|}{ East clade } \\
\hline & mean & $\min$ & $\max$ & $\mathrm{SD}$ & mean & $\min$ & $\max$ & $\mathrm{SD}$ & mean & $\min$ & $\max$ & $\mathrm{SD}$ & mean & $\min$ & $\max$ & $\mathrm{SD}$ \\
\hline $\mathrm{SL}(\mathrm{mm})$ & 40.1 & 28.3 & 54.7 & 8.8 & 35.5 & 26.0 & 50.9 & 6.9 & 41.5 & 27.5 & 61.8 & 9.0 & 35.4 & 25.4 & 50.9 & 6.8 \\
\hline \multicolumn{17}{|l|}{$\% \mathrm{SL}$} \\
\hline Anal fin - Anus & 4.8 & 3.4 & 6.4 & 0.9 & 4.2 & 3.4 & 5.0 & 0.5 & 5.2 & 3.8 & 6.5 & 0.7 & 5.6 & 4.4 & 6.6 & 0.6 \\
\hline Anal fin - Caudal fin & 21.6 & 19.0 & 25.0 & 1.7 & 20.2 & 17.6 & 22.3 & 1.1 & 20.9 & 18.8 & 24.4 & 1.3 & 20.9 & 19.0 & 23.6 & 1.3 \\
\hline Anal fin height & 15.9 & 14.4 & 17.9 & 0.9 & 16.2 & 14.3 & 17.7 & 0.8 & 16.7 & 14.5 & 19.4 & 1.2 & 16.0 & 13.9 & 18.7 & 1.3 \\
\hline Body depth & 23.0 & 20.9 & 25.7 & 1.7 & 24.8 & 21.7 & 28.7 & 1.6 & 25.2 & 21.4 & 29.2 & 2.1 & 22.6 & 19.9 & 24.9 & 1.4 \\
\hline Caudal peduncle depth & 12.1 & 11.1 & 13.1 & 0.7 & 12.4 & 11.4 & 13.2 & 0.5 & 13.1 & 11.8 & 13.8 & 0.6 & 12.4 & 11.7 & 13.0 & 0.3 \\
\hline Caudal peduncle length & 15.1 & 12.9 & 17.5 & 1.4 & 13.8 & 11.9 & 15.6 & 0.8 & 14.6 & 12.3 & 16.9 & 1.1 & 14.1 & 12.6 & 16.3 & 1.0 \\
\hline Dorsal fin height & 21.3 & 19.9 & 23.7 & 1.2 & 20.6 & 19.0 & 22.9 & 1.1 & 22.2 & 20.3 & 28.0 & 1.6 & 21.9 & 20.2 & 25.6 & 1.3 \\
\hline Head depth & 16.6 & 14.8 & 19.0 & 1.0 & 17.8 & 16.0 & 19.5 & 0.9 & 17.4 & 16.1 & 18.8 & 0.9 & 16.9 & 15.7 & 18.4 & 0.8 \\
\hline Head length & 23.9 & 21.2 & 27.2 & 1.4 & 25.3 & 22.0 & 27.1 & 1.2 & 24.2 & 21.9 & 27.5 & 1.5 & 24.8 & 21.7 & 27.3 & 1.3 \\
\hline Head width & 18.8 & 16.6 & 21.4 & 1.2 & 19.5 & 16.2 & 21.9 & 1.4 & 18.7 & 16.7 & 21.0 & 1.3 & 18.0 & 16.4 & 19.4 & 0.9 \\
\hline Internostral distance & 7.2 & 5.8 & 8.4 & 0.6 & 7.8 & 6.9 & 9.0 & 0.5 & 7.7 & 6.4 & 8.6 & 0.5 & 7.8 & 6.9 & 8.5 & 0.4 \\
\hline Interorbital width & 11.0 & 9.9 & 11.9 & 0.7 & 12.7 & 11.9 & 14.3 & 0.6 & 11.5 & 10.6 & 12.4 & 0.6 & 12.1 & 11.2 & 13.0 & 0.4 \\
\hline Pectoral fin height & 20.2 & 18.7 & 23.7 & 1.2 & 20.8 & 17.9 & 24.8 & 1.8 & 20.2 & 17.2 & 22.8 & 1.4 & 19.7 & 17.4 & 21.9 & 1.0 \\
\hline Pectoral fin - Pelvic fin & 33.0 & 30.2 & 35.1 & 1.3 & 30.9 & 27.5 & 33.8 & 1.6 & 31.7 & 28.6 & 33.8 & 1.4 & 31.3 & 29.4 & 34.1 & 1.4 \\
\hline Postorbital length & 9.23 & 7.8 & 10.6 & 0.8 & 10.2 & 8.6 & 12.0 & 0.8 & 9.1 & 8.0 & 10.5 & 0.6 & 9.1 & 7.8 & 11.1 & 0.8 \\
\hline Postdorsal length & 35.8 & 32.0 & 38.4 & 1.8 & 34.8 & 31.6 & 37.8 & 1.4 & 35.9 & 33.4 & 38.5 & 1.7 & 35.1 & 32.2 & 39.0 & 1.6 \\
\hline Preanal length & 78.6 & 76.0 & 81.1 & 1.5 & 79.3 & 77.4 & 81.3 & 1.0 & 78.6 & 75.3 & 81.2 & 1.4 & 79.0 & 76.0 & 81.0 & 1.2 \\
\hline Predorsal length & 51.6 & 49.5 & 54.5 & 1.4 & 51.9 & 50.5 & 54.2 & 1.1 & 50.9 & 49.0 & 53.6 & 1.2 & 50.8 & 47.7 & 53.3 & 1.4 \\
\hline Prepelvic length & 56.0 & 52.2 & 59.2 & 2.0 & 55.6 & 52.9 & 58.2 & 1.4 & 54.6 & 52.2 & 58.5 & 1.4 & 54.7 & 51.4 & 57.5 & 1.4 \\
\hline Pelvic fin - Anal fin & 22.5 & 20.3 & 25.1 & 1.6 & 23.3 & 20.5 & 25.1 & 1.2 & 23.6 & 22.1 & 26.4 & 1.2 & 24.0 & 19.7 & 26.8 & 1.6 \\
\hline Pelvic fin - Caudal fin & 44.2 & 39.9 & 48.5 & 1.9 & 43.9 & 40.7 & 46.4 & 1.3 & 45.0 & 39.9 & 47.5 & 1.8 & 45.0 & 41.3 & 49.0 & 1.6 \\
\hline Pelvic fin height & 16.6 & 15.2 & 18.8 & 1.0 & 16.8 & 15.2 & 19.2 & 1.0 & 16.9 & 15.0 & 19.8 & 1.2 & 16.8 & 14.5 & 18.4 & 1.0 \\
\hline Snout length & 10.5 & 8.2 & 12.2 & 1.0 & 10.3 & 9.0 & 12.1 & 1.0 & 10.8 & 9.7 & 12.5 & 0.8 & 10.6 & 9.2 & 12.7 & 1.0 \\
\hline \multicolumn{17}{|l|}{$\% \mathrm{HL}$} \\
\hline Head depth & 69.4 & 62.4 & 74.8 & 3.1 & 70.3 & 62.4 & 74.7 & 2.9 & 72.4 & 63.2 & 78.2 & 4.0 & 68.1 & 63.6 & 78.6 & 3.4 \\
\hline Head width & 78.7 & 70.0 & 90.2 & 5.4 & 77.2 & 64.8 & 89.9 & 5.2 & 77.6 & 70.3 & 84.2 & 4.0 & 72.8 & 65.4 & 79.6 & 3.2 \\
\hline Internostral distance & 30.2 & 27.3 & 33.7 & 1.6 & 30.8 & 27.0 & 34.8 & 1.7 & 31.7 & 27.2 & 34.7 & 1.9 & 31.4 & 26.9 & 34.1 & 1.7 \\
\hline Interorbital width & 46.4 & 41.7 & 50.2 & 2.9 & 50.1 & 46.3 & 54.9 & 2.3 & 48.0 & 38.5 & 55.7 & 4.4 & 49.0 & 44.0 & 54.0 & 2.6 \\
\hline Orbit diameter & 20.8 & 19.5 & 23.5 & 1.1 & 21.4 & 18.9 & 25.0 & 1.6 & 22.1 & 19.4 & 25.0 & 1.6 & 22.7 & 20.4 & 24.7 & 1.3 \\
\hline Postorbital length & 38.7 & 33.6 & 43.9 & 2.8 & 40.4 & 36.3 & 46.6 & 2.6 & 38.0 & 32.7 & 43.2 & 3.4 & 36.6 & 34.1 & 41.5 & 1.9 \\
\hline Snout length & 44.1 & 38.1 & 49.0 & 3.2 & 40.6 & 35.1 & 46.3 & 3.4 & 44.7 & 36.9 & 48.5 & 2.2 & 42.9 & 36.9 & 48.5 & 3.0 \\
\hline
\end{tabular}

numbers of scale rows were taken. Vertebrae were counted as precaudal, intermediate and caudal vertebrae, without including the urostyle. Precaudal vertebrae have no closed haemal arches and caudal vertebrae have a joined parapophyses forming an arch. The parapophyses of the ultimate precaudal vertebrae may be joined by a bony bridge, forming a narrow arch, but their ends are not joined (Ahnelt and Duchkowitsch 2004). In this case these vertebrae were counted as intermediate vertebrae. Since the posterior two rays of the dorsal fin and the anal fin are branches of the same ray, they were counted as $1 \frac{1}{2}$. Unbranched dorsal fin rays and unbranched anal fin rays could only be counted via micro $\mathrm{CT}$ images.

For micro CT scanning, 30 individuals were used (West clade: $n=7$; Central clade: $\mathrm{n}=7$; North clade: $n=8$; East clade: $\mathrm{n}=8$ ). The fish were mounted 
vertically in plastic tubes containing $70 \%$ ethanol. The diameter of sample holder tubes was $12 \mathrm{~mm}$. For each tube two fish were mounted in opposite direction. Micro CT scans were acquired using a Scanco $\mu$ CT35 (SCANCO Medical AG, Brüttisellen, Switzerland) at $70 \mathrm{kVp}$ source voltage and $114 \mu \mathrm{A}$ intensity. Projections were recorded with $420 \mathrm{~ms}$ integration time (camera binning $=2$ ) and an angular increment of $0.36^{\circ}$. Reconstructed slices measured $1024 \times 1024$ pixel, and isotropic voxel resolution of reconstructed volumes was $12 \mu \mathrm{m}$. Image processing and analysis was done using Fiji (Schindelin et al. 2012; Fiji ImageJ version 2.0.0) and Amira 6 (FEI Visualization Sciences Group, Mérignac Cédex, France).

\section{Morphometrics}

Morphometric measurements of the preserved specimens of $G$. barreimiae are given for each clade in Table 2. All measurements show overlaps between all of the mt clades of $G$. barreimiae, although many measurements show significant differences (Table 3). A probability value of less than 0.05 of the statistical tests was considered significant. The following measurements are not normally distributed and are thus not suitable for ANOVA, Tukey's HSD test and PCA: body depth (West clade), dorsal fin height (North clade), head depth in \% of head length (East clade and Central clade), predorsal length (Central clade), pectoral fin length (West clade). The following measurements have no equality of variance and are thus not suitable for ANOVA, Tukey's HSD and PCA: pectoral fin length, caudal peduncle length, interorbital width in $\%$ of head length, anal fin - anus, postorbital length in $\%$ of head length, caudal peduncle depth. Parametric measurements which show significant differences between the clades in ANOVA are plotted in Fig. 2.

Results for Levene's test, ANOVA and KruskalWallis test are given in the appendix. Results for Tukeys HSD test are shown in Table 3 based on the results of ANOVA.

In the PCA (Fig. 3) PC1 explains $51.65 \%$ of the variance and $\mathrm{PC} 2$ explains $19.61 \%$ of the variance. Ellipses with $75 \%$ tolerance are used in the plot. The four different clades are widely overlapping. In the LDA Axis 1 (Fig. 4) explains $53.19 \%$ of the variance. Axis 2 explains $41.16 \%$ of the variance. The four clades are overlapping but also differentiated to some extent, especially the West clade and the Central clade. $75.86 \%$ (63.22\% Jackknife tested) of all specimens are correctly classified in the confusion matrix.

\section{Meristics}

Vertebral numbers, positions of dorsal fin and anal fin pterygophores, pharyngeal teeth and unbranched dorsal and anal fin rays were counted using micro CT. Other structures were counted using light microscopy. Meristics were summarized in Table 4. Meristics of gill rakers, vertebrae and branched pelvic fin rays can be used to distinguish the West clade from the other clades. Intermediate vertebral numbers: one in West clade (Fig. 5) versus mostly two in the other clades (Fig. 6), mostly i,7 pelvic fin rays in the West clade and i,8 in the

Table 3 Tukey's honest significant difference test of parametric morphometric measurements of the four clades depicts which clades differ significantly from one another in specific measurements

\begin{tabular}{lllll}
\hline West Central & West North & West East & Central East & Central North \\
\hline AFCDF & INTN\%HL & HW\%HL & BD & HL \\
0.0069 & 0.0152 & 0.0005 & 0.0006 & 0.0266 \\
HL & OD\%HL & OD\%HL & HW\%HL & SNL\%HL \\
0.0036 & 0.0159 & 0.0003 & 0.0125 & 0.0003 \\
PCTPV & PCTPV & PCTPV & OD $\%$ HL & \\
0.0002 & 0.0217 & 0.002 & 0.0158 & \\
SNL\%HL & PRPV & PRPV & & \\
0.0016 & 0.019 & 0.038 & & \\
& PVFAF & PVFAF & & \\
& 0.0464 & 0.0045 & & \\
\end{tabular}

AFCDF: anal fin - caudal fin; BD: body depth; HL: head length; HW\%HL: head width in \% of head length; INTN\%HL: internostral distance in \% of head length; OD\%HL: orbit diameter in \% of head length; PCTPV: pectoral fin - pelvic fin; PRPV: prepelvic length; PVFAF: pelvic fin - anal fin; SNL\%HL: snout length in $\%$ of head length 

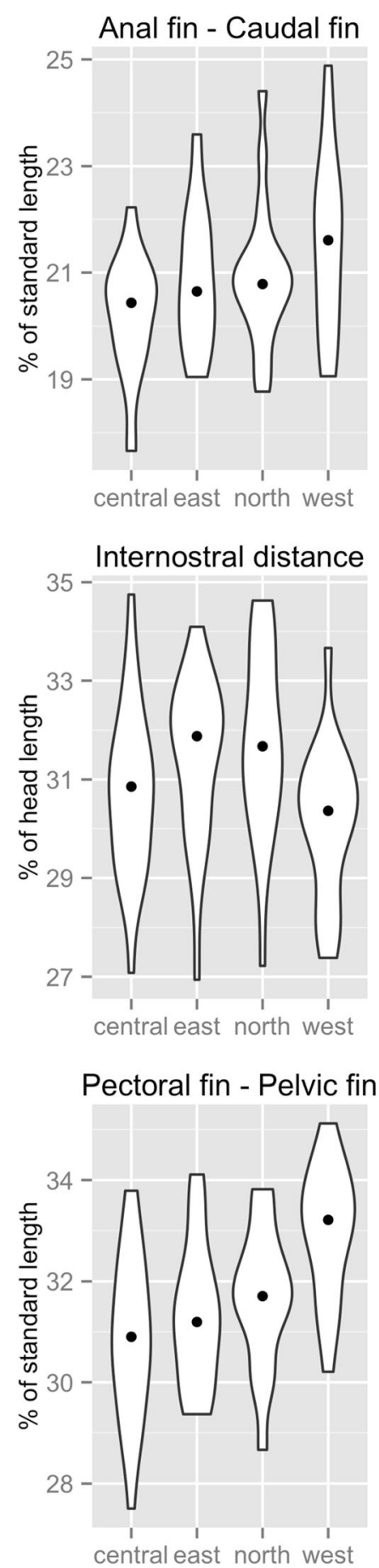
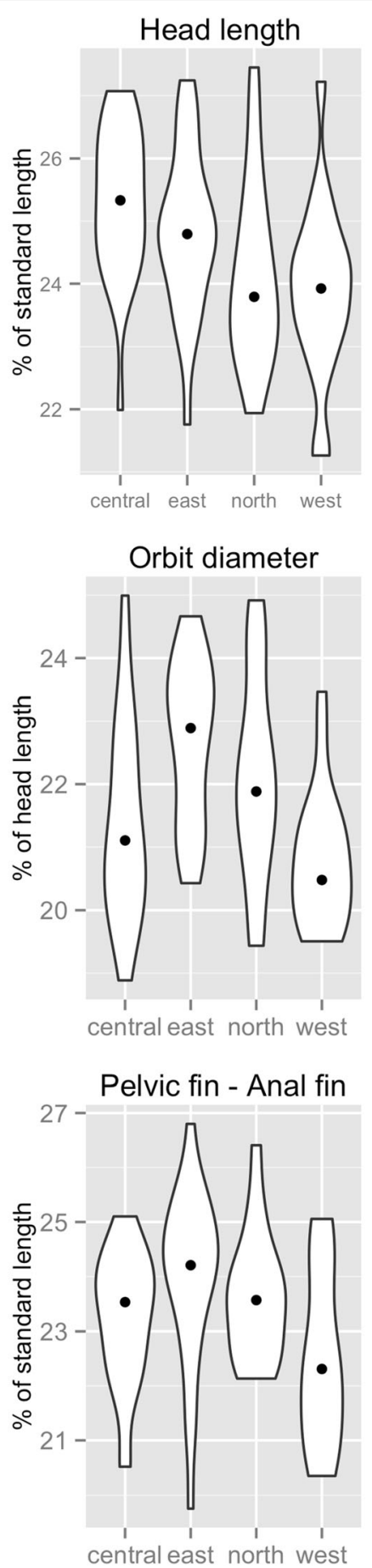
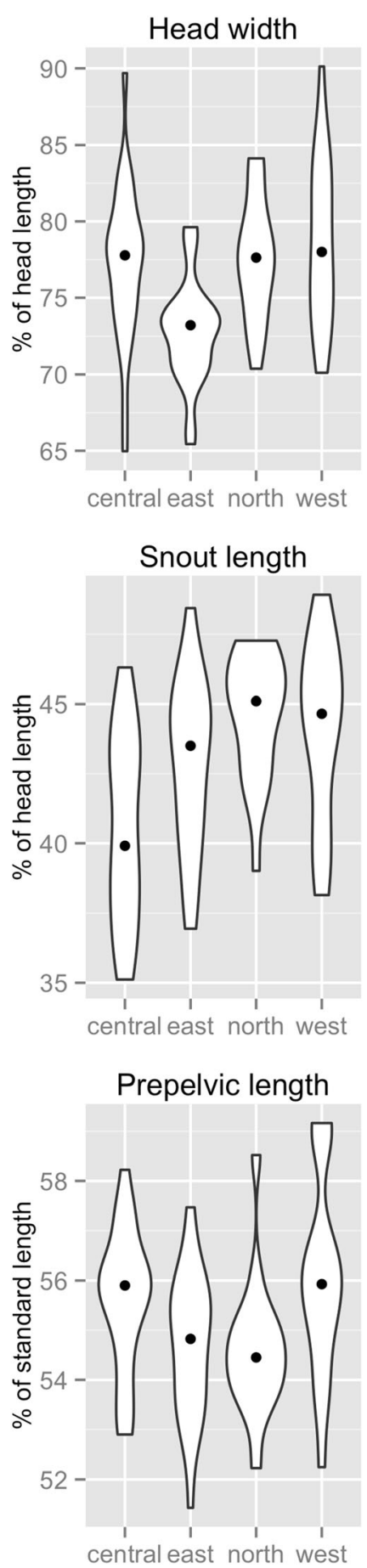

Fig. 2 Violin plots based on nine parametric measurements which show significant differences between the four mt clades (x-axis) in Oneway ANOVA. The median is shown in each plot as a black dot

other clades (Fig. 7). Typically, there are 17 precaudal vertebrae in the East clade, 18 in the Central clade and North clade and 19 in the West clade, although there are overlaps. There are 15 to 17 gill rakers on the lower limb of the first gill arch in the West clade, clearly separating it from the other clades with 12 to 14 in the Central clade and 10 to 14 in the North clade and East clade. Across all clades the following traits are quite stable: Dorsal fin 


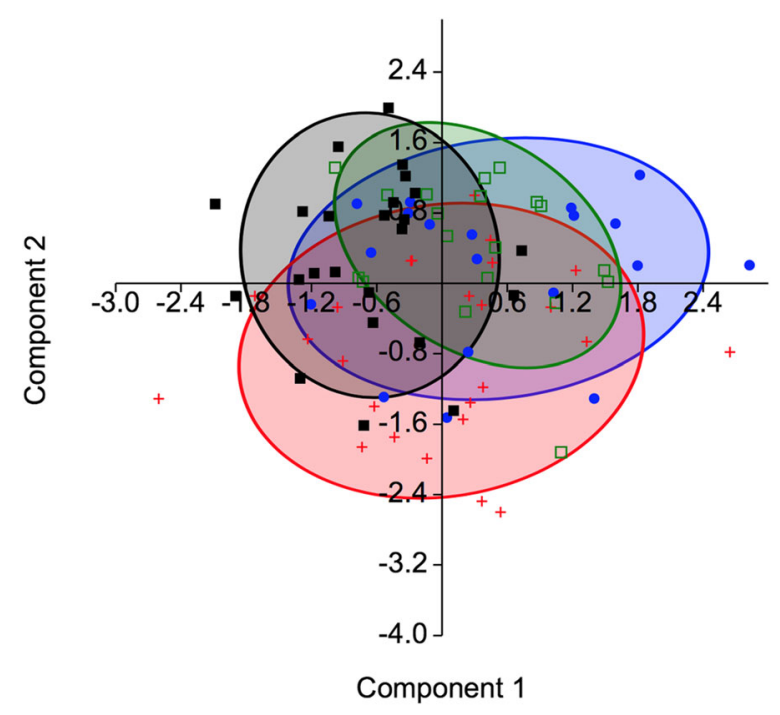

Fig. 3 PCA of significant parametric measurements with ellipses indicating $75 \%$ tolerance. PC1 explains $51.65 \%$ of the variance and PC2 explains $19.61 \%$ of the variance. West clade: blue, Central clade: red, North clade: green, East clade: black

rays of all clades are iii, $71 \frac{1}{2}$ and anal fin rays are iii, $51 \frac{1}{2}$. Individual cases of two unbranched anal fin rays as well as $4 \frac{1}{2}$ branched anal fin rays occur. The first two pectoral fin rays of Garra are usually unbranched (Lundberg and Marsh 1976; Stiassny and Getahun 2007). In G. barreimiae, however, one or two unbranched fin rays are present, but one unbranched pectoral fin ray is the common case. The number of branched rays is very

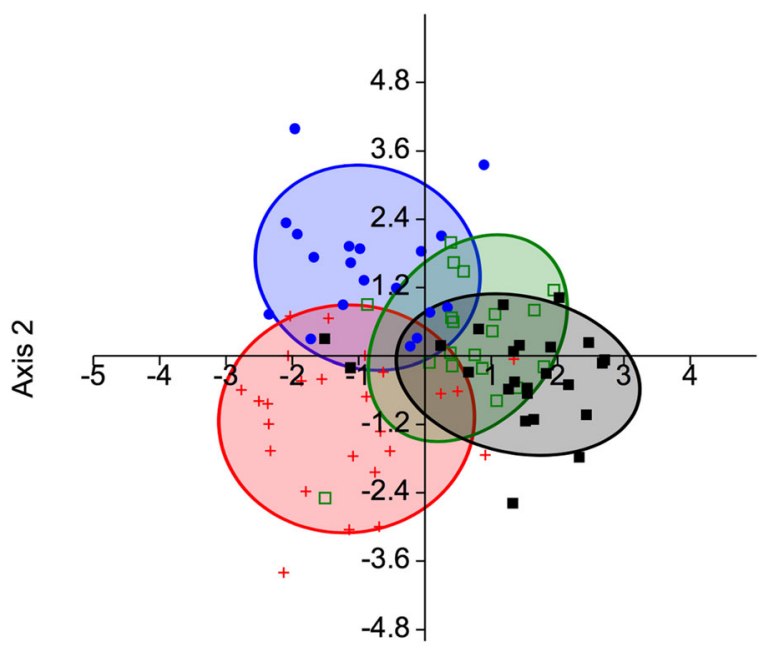

Axis 1

Fig. 4 LDA of significant parametric measurements with ellipses indicating $75 \%$ tolerance. Axis 1 explains $53.19 \%$ of the variance. Axis 2 explains $41.16 \%$ of the variance. West clade: blue, Central clade: red, North clade: green, East clade: black variable. The first unbranched dorsal fin ray and anal fin ray as well as the final branched pectoral fin rays often are extremely small and thus hard to detect. The caudal fin usually has 10 upper and nine lower principal fin rays (equivalent to $9+8$ branched caudal fin rays). Gill rakers are small, sometimes only knob-like, very fragile and present on the lower limb (ceratobranchial), but sometimes missing on the upper limb (epibranchial). There are 12 or 13 predorsal scales with individual cases of 11 or 14 predorsal scales, however the pattern very often is irregular. There are four scales above the lateral line and three scales below the lateral line. Individual cases of five scales above the lateral line and four scales below the lateral line occur. All fish have four barbels. Pharyngeal teeth are in three rows: typically 2.4.5-5.4.2. Teeth numbers of $1.2 .5,1.3 .5$ or 2.3 .5 occur.

\section{Discussion}

With the introduction of molecular genetic methods into phylogenetic questions, distinct lineages in G. barreimiae have been detected recently (Kirchner et al. 2017). Our results show that at least some of these lineages are differentiated by morphological characters. All specimens of this study have originally been caught for genetic analyses only. Therefore, the samples sometimes did not represent the full size spectrum of a population and contained many small individuals. However, this study is based on the largest number of morphologically examined specimens of the G. barreimiae species complex to this point. The morphometric work that had been previously performed on G. barreimiae yielded contradicting results, which could be interpreted as even higher morphological variability than observed in the present study. Yet they could also be explained by different techniques of measurement and counting. As an example, the number of dorsal fin rays was stated as iii,7 by Fowler and Steinitz (1956), iii,6 by Menon (1964), iv, 6 or 8 by Banister and Clarke (1977) and iv, $6-8$ by Krupp (1983). As demonstrated in the results, all specimens in this study had iii, $7_{1 / 2}$ dorsal fin rays. Especially the first unbranched dorsal fin ray often is rather small and could be observed in greater detail using micro CT.

Banister \& Clarke divided G. barreimiae into G. $b$. shawkahensis (from one locality in Wadi Shawkah) and G. b. barreimiae (from all other mentioned localities and collections) based on a different number of gill rakers on the lower limb of the first gill arch (G. b. barreimiae: 
Table 4 Meristic counts and associated number of specimens per clade. Dorsal fin pterygophore insertion refers to the precaudal vertebrae number anterior to the first major dorsal fin pterygophore. Anal fin pterygophore insertion refers to the caudal vertebrae number anterior to the first major anal fin pterygophore

\begin{tabular}{|c|c|c|c|c|c|}
\hline & Count & West & Central & North & East \\
\hline \multirow[t]{3}{*}{ Precaudal vertebrae } & 17 & - & - & 2 & 7 \\
\hline & 18 & 1 & 6 & 5 & - \\
\hline & 19 & 6 & 1 & 1 & - \\
\hline \multirow[t]{3}{*}{ Intermediate vertebrae } & 1 & 7 & 1 & 1 & 2 \\
\hline & 2 & - & 6 & 6 & 5 \\
\hline & 3 & - & - & 1 & - \\
\hline \multirow[t]{3}{*}{ Caudal vertebrae } & 12 & 1 & 1 & 1 & - \\
\hline & 13 & 5 & 4 & 6 & 4 \\
\hline & 14 & 1 & 1 & 1 & 3 \\
\hline \multirow[t]{4}{*}{ Total vertebrae } & 31 & - & - & - & 1 \\
\hline & 32 & 1 & 1 & 1 & 4 \\
\hline & 33 & 6 & 4 & 7 & 2 \\
\hline & 34 & - & 1 & - & - \\
\hline \multirow{3}{*}{$\begin{array}{l}\text { Dorsal fin pterygophore } \\
\text { insertion }\end{array}$} & 10 & - & 3 & 4 & 6 \\
\hline & 11 & 6 & 4 & 4 & 1 \\
\hline & 12 & 1 & - & - & - \\
\hline \multirow{3}{*}{$\begin{array}{l}\text { Anal fin pterygophore } \\
\text { insertion }\end{array}$} & 1 & 2 & 1 & 5 & 1 \\
\hline & 2 & 5 & 6 & 2 & 5 \\
\hline & 3 & - & - & 1 & 1 \\
\hline \multirow[t]{4}{*}{ Lateral line scales } & 30 & - & 6 & 6 & 2 \\
\hline & 31 & 11 & 16 & 11 & 13 \\
\hline & 32 & 6 & 3 & 2 & 8 \\
\hline & 33 & 2 & - & - & - \\
\hline \multirow{3}{*}{$\begin{array}{l}\text { Lateral scales on caudal } \\
\text { fin base }\end{array}$} & 1 & - & 1 & - & - \\
\hline & 2 & 11 & 23 & 8 & 17 \\
\hline & 3 & 8 & 1 & 11 & 6 \\
\hline \multirow[t]{4}{*}{ Total lateral scale count } & 32 & - & 6 & - & 2 \\
\hline & 33 & 6 & 16 & 13 & 7 \\
\hline & 34 & 8 & 3 & 5 & 14 \\
\hline & 35 & 5 & - & 1 & - \\
\hline \multirow{4}{*}{$\begin{array}{l}\text { Scales between anus } \\
\text { and anal fin }\end{array}$} & 1 & - & 2 & 1 & 3 \\
\hline & 2 & 17 & 20 & 10 & 11 \\
\hline & 3 & 2 & 3 & 8 & 7 \\
\hline & 4 & - & - & - & 1 \\
\hline \multirow{4}{*}{$\begin{array}{l}\text { Scales between anus } \\
\text { and pelvic fin }\end{array}$} & 4 & 2 & - & - & 2 \\
\hline & 5 & 4 & 1 & 5 & 3 \\
\hline & 6 & 11 & 16 & 10 & 16 \\
\hline & 7 & 1 & 8 & 3 & 2 \\
\hline \multirow[t]{3}{*}{ Postdorsal scales } & 13 & - & 1 & - & 6 \\
\hline & 14 & 4 & 3 & 2 & 4 \\
\hline & 15 & 7 & 8 & 14 & 10 \\
\hline
\end{tabular}

Table 4 (continued)

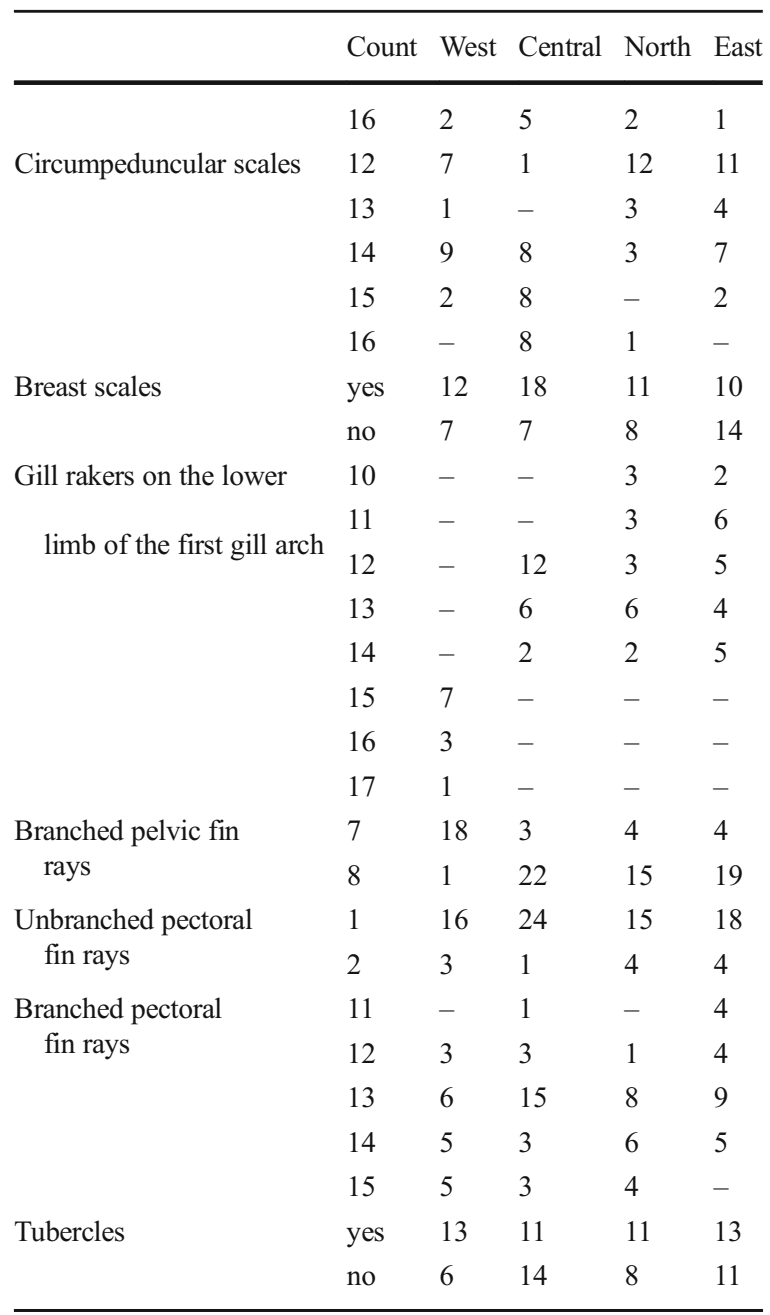

11-14; G. b. shawkahensis: 15-18) and a different mean prepelvic distance (G. b. barreimiae: $53.9 \%$; G. $b$. shawkahensis: $56.2 \%$ ). They also described G. longipinnis from the Saiq region based on eight specimens with strikingly long paired fins (Banister and Clarke 1977) like the pectoral fins with 23.3$32.9 \%$. Saiq is within the region of this study's Central clade and Hamidan et al. (2014) identified fish from that area as $G$. cf. longipinnis. The pectoral fin is variable in the Central clade with a range of 17.9-24.8\%, thus some specimens would fit the lower range values of the original species description of $G$. longipinnis, however the mean height of the pectoral fins is not longer in the Central clade than in the others. Krupp (1983) published a species key for Arabian Garra in which G. b. barreimiae should have less than fifteen gill rakers on 
Fig. 5 Micro CT image of selected specimens of the West clade: all examined West clade specimens have one intermediate vertebra (indicated with red arrow). The upper image (a) shows the whole skeleton, the lower image (b) represents a detailed view on the intermediate vertebra, caudal vertebra and the anal fin
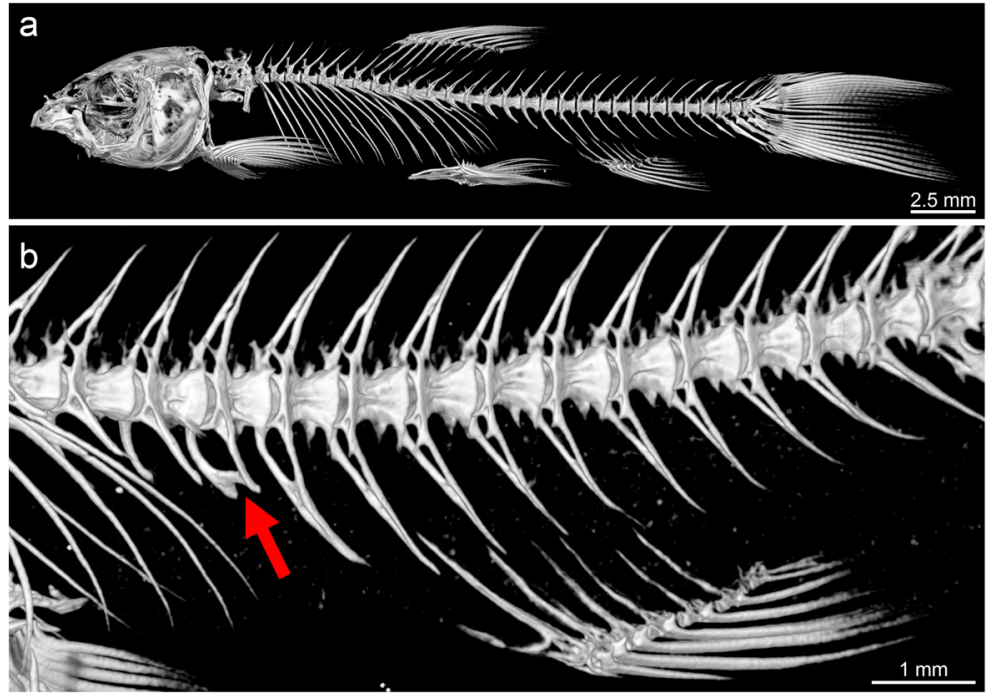

the lower limb of the first gill arch and G. $b$. shawkahensis should have more than fourteen gill rakers, which was the substantial morphological difference between the two subspecies.

In this study, the mean prepelvic distance is the largest in the West clade with $56.0 \%$ (Fig. 2, Table 2) and thus in fact very close to that reported by Banister and Clarke (1977) $(56.2 \%)$ for G. b. shawkahensis. In addition, all West clade specimens have more than 14 gill rakers on the lower limb of the first gill arch, further fitting the description of G. b. shawkahensis of Banister and Clarke as well as that of Krupp (1983). One might be tempted to expand the known range of $G$. $b$. shawkahensis by our three West clade sampling sites, but things may be more complicated. Fowler and Steinitz did not measure the prepelvic distance and did not count gill rakers in their original description of G. barreimiae. Banister and Clarke did not take measurements of specimens from Buraimi, but considered them to belong to the same taxon as specimens from Wadi Sahtan, a locality that clearly belongs to another genetic clade (North clade), as well as fishes from undisclosed regions of Oman. In an analysis of $\mathrm{mt}$ sequences (Kirchner et al. 2017) fishes from Wadi Shawkah did cluster together with specimens from the West clade (Hafeet, Hayyal and Al Juwayf).
Fig. 6 Micro CT image of an East clade specimen. The Central, North, or East clade usually have two intermediate vertebrae (indicated by red arrows). The upper image (a) shows the whole skeleton, the lower image (b) shows details of the intermediate vertebrae, caudal vertebrae and the anal fin
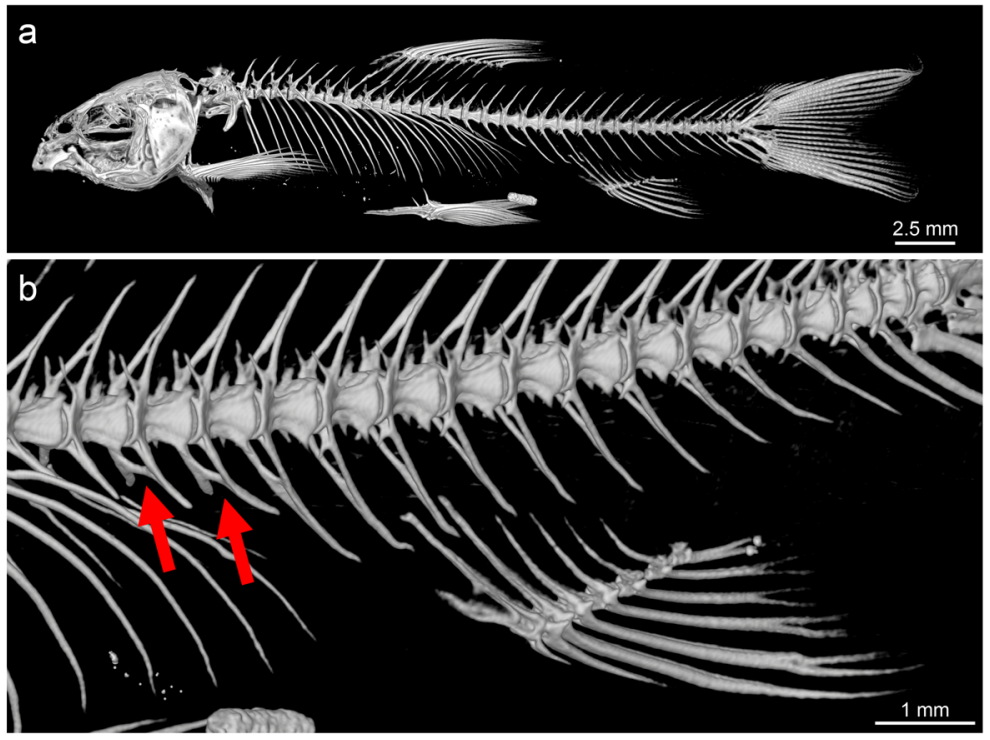

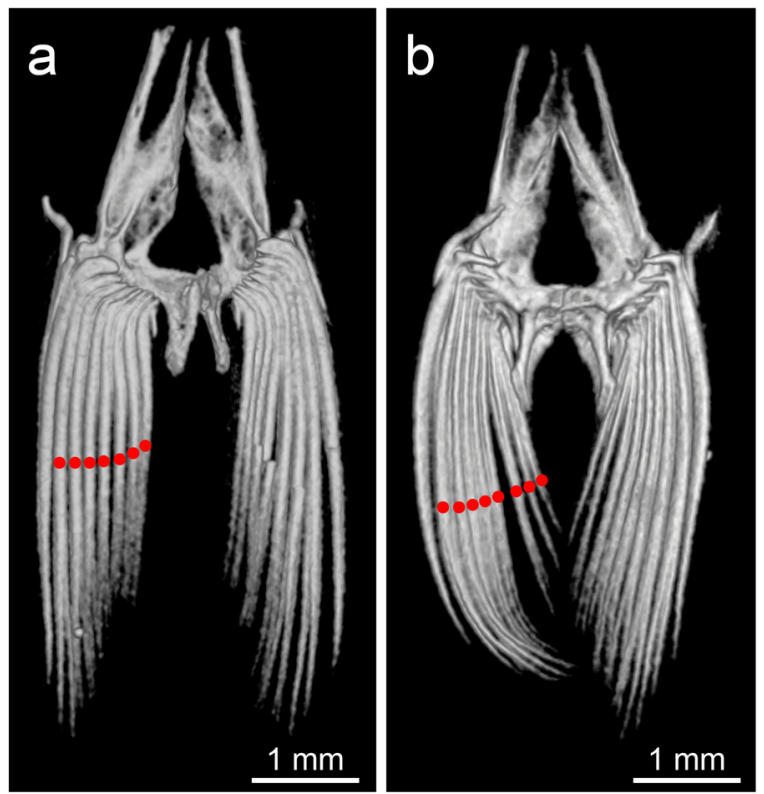

Fig. 7 Variations of pelvic fin ray numbers. West clade specimens (a) typically have i,7 pelvic fin rays, while the other clades (b), with a Central clade specimen depicted, usually have i,8 pelvic fin rays. Branched fin rays are marked by red dots

Furthermore, all sampling sites from the West clade and the original description sites of G. barreimiae and $G$. $b$. shawkahensis are found in the same region, the western slopes of the Al Hajar Mountains (Fig. 1). In the Catalog of Fishes G. b. shawkahensis is considered to be a synonym of G. barreimiae (Eschmeyer et al. 2017). During two collection trips of the Natural History Museum Vienna, the original description site of G. barreimiae, Buraimi, was visited, but no fish could be found. Type specimens have not been examined in this study, thus comparisons refer exclusively to literature. However, it is very likely that Fowler \& Steinitz' G. barreimiae, Banister \& Clark's G. b. shawkahensis and this study's specimens from the sampling sites Hafeet, Hayyal and Al Juwayf belong to the same taxon. The West clade fits the original description of G. barreimiae best, both concerning distribution and morphology. Whether the classification of $G$. $b$. shawkahensis as subspecies is justified, remains open at the current stage of knowledge.

The sampling locations of the mt clades Central and East have not been mentioned in any valid species description. Individuals belonging to the North clade have at least partially falsely been grouped together with individuals of G. b. barreimiae in the past. All morphometric measurements overlap between the clades and are very variable within the clades (Fig. 2, Table 2). The clades are not separated in the PCA (Fig. 3), although in the LDA (Fig. 4) the West clade, Central clade and East clade are distinguishable and most specimens can be correctly classified based on the same measurements in the confusion matrix. A noteworthy difference is the pelvic fin ray count with seven branched rays in most of the West clade specimens and eight branched rays in most specimens of the other clades (Table 4; Fig. 7). The West clade also has generally nineteen precaudal and one intermediate vertebrae, both of which are very uncommon in the other clades. All East clade specimens have seventeen precaudal vertebrae, a feature apart from that only found in two of the North clade specimens.

\section{Conclusion}

Besides the number of gill rakers, which distinctly separates the West clade from the other clades, no clearly well-defined morphological character distinguishing the clades could be identified with the methods applied. Several morphometric measurements however, display significant differences between the clades. Measurements of head structures are particularly conspicuous in all clades and therefore should be considered as primary targets of more precise morphological methods (e.g. geometric morphometrics). Besides a few overlaps, the numbers of precaudal and intermediate vertebrae as well as those of branched pelvic fin rays indicate that the West clade is morphologically distinct from the other clades. The original descriptions of G. barreimiae and G. b. shawkahensis correspond to the West clade both geographically and morphologically. According to the concept of Integrative Taxonomy multiple disciplines should be used for species delimitation with morphology and methods revealing nuclear genetic information always being applied (SchlickSteiner et al. 2010). Thus, concerning the Central clade, North clade and East clade, the question whether they represent separate taxa has to be addressed combining genetic and morphological data.

Acknowledgements Open access funding provided by University of Vienna. We thank Oliver Macek, Julia Schindelar, Barbara Tautscher and Lorena Toscano for their continued support in the lab, as well as Robert Illek and Lukas Plan for helping with the collection of samples. We want to express our gratitude to the Ministry of Environment and Climate Affairs of Oman and the Austrian Economy Chambers for their cooperation, support and sampling permits. 


\section{Appendix}

Table 5 Results of Levene's test for homogeneity of variance, ANOVA and Kruskal-Wallis test for each morphometric measurement. In the case of nonparametric data, results of the Kruskal-Wallis test are preferable over ANOVA. In this case results of the Kruskal-Wallis test are written in bold letters. A probability value of less than 0.05 is considered significant

\begin{tabular}{|c|c|c|c|}
\hline & Levene's test & ANOVA & Kruskal-Wallis test \\
\hline Anal fin - Anus & 0.0012 & $2.460 \mathrm{E}-10$ & $3.652 \mathrm{E}-08$ \\
\hline Anal fin - Caudal fin & 0.2325 & 0.0125 & 0.0430 \\
\hline Anal fin height & 0.0881 & 0.0808 & 0.1639 \\
\hline Body depth & 0.6192 & $1.263 \mathrm{E}-06$ & $1.445 \mathrm{E}-05$ \\
\hline Caudal peduncle depth & 0.0035 & $1.649 \mathrm{E}-06$ & $9.943 \mathrm{E}-05$ \\
\hline Caudal peduncle length & 0.0170 & 0.0006 & 0.0033 \\
\hline Dorsal fin height & 0.9175 & 0.0003 & 0.0002 \\
\hline Head depth (\% of HL) & 0.4949 & 0.0007 & 0.0005 \\
\hline Head length & 0.8436 & 0.0023 & 0.0013 \\
\hline Head width (\% of HL) & 0.1002 & 0.0002 & 0.0002 \\
\hline Internostral dist. (\% of HL) & 0.8597 & 0.0196 & 0.0114 \\
\hline Interorbital width ( $\%$ of HL) & 0.0367 & 0.0012 & 0.0032 \\
\hline Orbit diameter ( $\%$ of $\mathrm{HL})$ & 0.2250 & 0.0001 & 0.0002 \\
\hline Pectoral fin height & 0.0154 & 0.0625 & 0.1778 \\
\hline Pectoral fin - Pelvic fin & 0.7127 & 0.0001 & 0.0030 \\
\hline Postorbital length ( $\%$ of HL) & 0.0040 & $4.836 \mathrm{E}-05$ & 0.0001 \\
\hline Postdorsal length & 0.3254 & 0.0539 & 0.0777 \\
\hline Preanal length & 0.1987 & 0.1715 & 0.1955 \\
\hline Predorsal length & 0.7126 & 0.0079 & 0.0335 \\
\hline Prepelvic length & 0.3664 & 0.0105 & 0.0036 \\
\hline Pelvic fin - Anal fin & 0.4907 & 0.0063 & 0.0180 \\
\hline Pelvic fin - Caudal fin & 0.6056 & 0.0895 & 0.1220 \\
\hline Pelvic fin height & 0.8987 & 0.8523 & 0.7766 \\
\hline Snout length (\% of HL) & 0.1126 & $9.016 \mathrm{E}-05$ & 0.0003 \\
\hline
\end{tabular}

Table 6 Confusion matrix of LDA. $75.86 \%$ of specimens were correctly classified based on significant parametric measurements. Rows show the given groups, columns show the predicted groups

\begin{tabular}{llllll}
\hline & West & Central & North & East & Total \\
\hline West & 15 & 0 & 4 & 0 & 19 \\
Central & 2 & 19 & 1 & 3 & 25 \\
North & 2 & 1 & 12 & 4 & 19 \\
East & 1 & 1 & 2 & 20 & 24 \\
Total & 20 & 21 & 19 & 27 & 87 \\
\hline
\end{tabular}

Table 7 Confusion matrix of LDA. After Jackknife resampling $63.22 \%$ of specimens were correctly classified based on significant parametric measurements. Rows show the given groups, columns show the predicted groups

\begin{tabular}{llllll}
\hline & West & Central & North & East & Total \\
\hline West & 12 & 1 & 6 & 0 & 19 \\
Central & 2 & 18 & 2 & 3 & 25 \\
North & 2 & 1 & 9 & 7 & 19 \\
East & 1 & 1 & 6 & 16 & 24 \\
Total & 17 & 21 & 23 & 26 & 87 \\
\hline
\end{tabular}



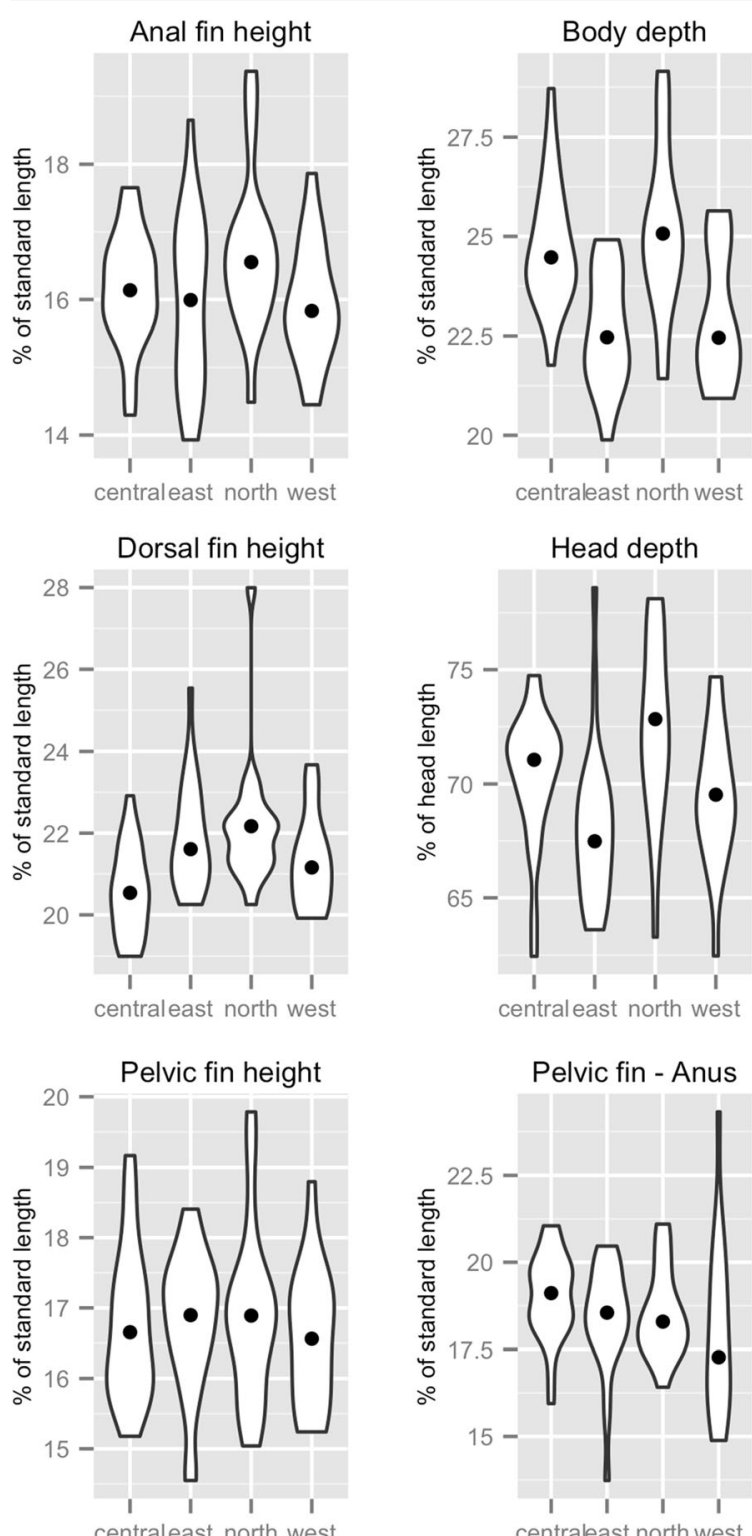

centraleast north west

Postorbital head length

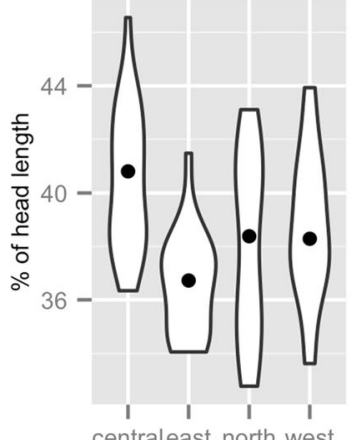

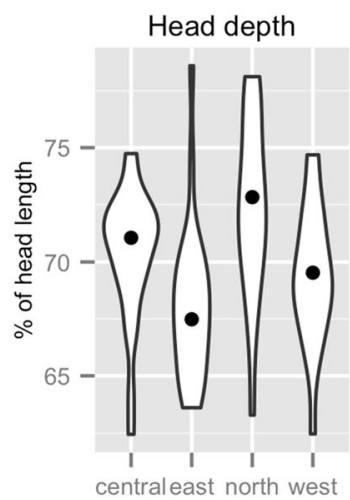

Pelvic fin - Anus

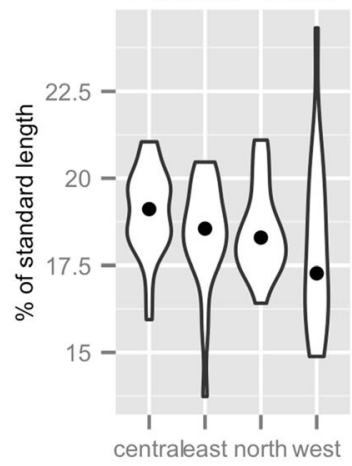

Preanal length

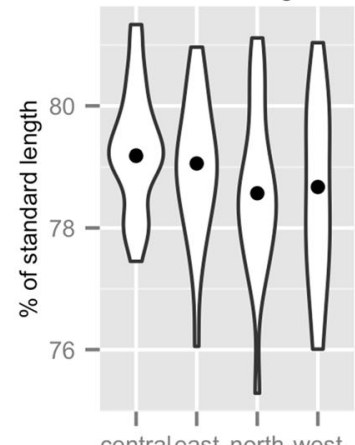

Caudal peduncle depth
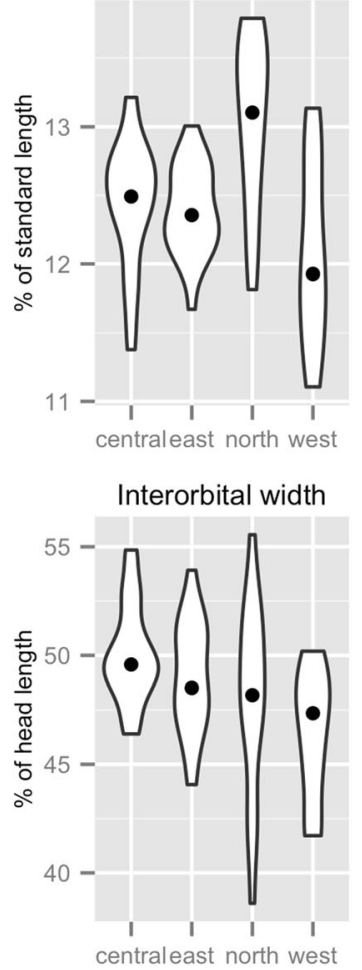

Pelvic fin - Caudal fin

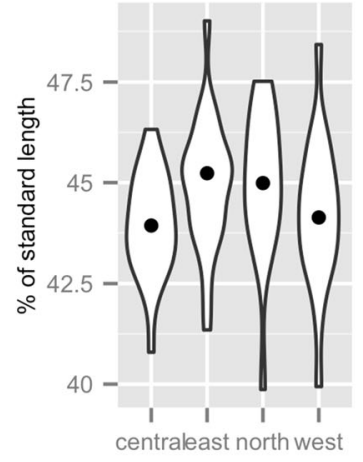

Predorsal length

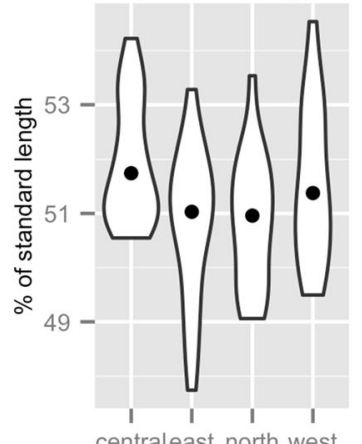

Caudal peduncle length
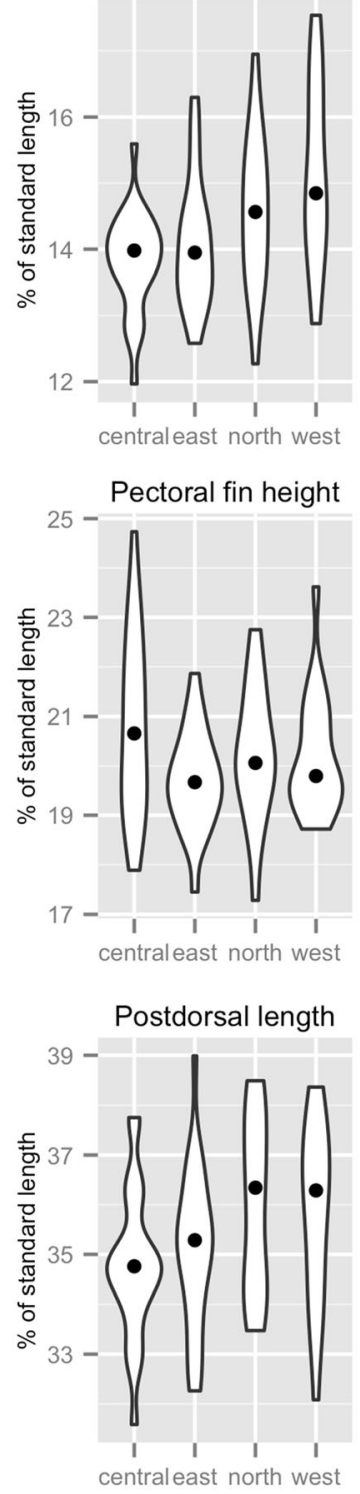

Standard length

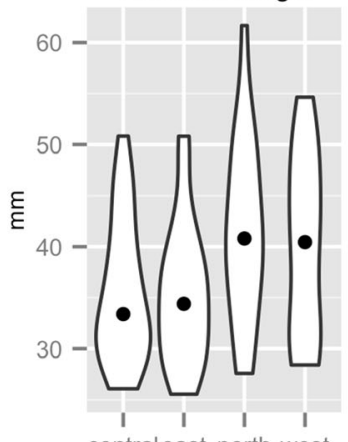

Fig. 8 Violin plots of non-parametric measurements of the four mt clades (in \% of standard length and \% of head length) and absolute measurements of the standard length. The median is shown in each plot as a black dot 
Open Access This article is distributed under the terms of the Creative Commons Attribution 4.0 International License (http:// creativecommons.org/licenses/by/4.0/), which permits unrestricted use, distribution, and reproduction in any medium, provided you give appropriate credit to the original author(s) and the source, provide a link to the Creative Commons license, and indicate if changes were made.

\section{References}

Ahnelt H, Duchkowitsch M (2004) The postcranial skeleton of Proterorhinus marmoratus with remarks on the relationships of the genus Proterorhinus (Teleostei : Gobiidae). J Nat Hist 38:913-924. https://doi.org/10.1080/0022293021000047873

Al-Rawahi MN, Brinkmann K, Schlecht E, Buerkert A (2014) Effects of changing water availability on land use in irrigated mountain oases of Al Jabal Al Akhdar, northern Oman. Erde 145:197-211. https://doi.org/10.12854/erde-145-18

Armbruster JW (2012) Standardized measurements, landmarks, and meristic counts for cypriniform fishes. Zootaxa 3586:8-16

Banister KE (1984) A subterranean population of Garra barreimiae (Teleostei: Cyprinidae) from Oman, with comments on the concept of regressive evolution. J Nat Hist 18: 927-938. https://doi.org/10.1080/00222938400770811

Banister KE (1987) Two new species of Garra (TeleosteiCyprinidae) from the Arabian peninsula. Bull Br Museum Natural Hist 52:59-70

Banister KE, Clarke MA (1977) The freshwater fishes of the Arabian peninsula. J Oman Stud:132-144

Eschmeyer WN, Fricke R, van der Laan R (eds) (2017) CATALOG OF FISHES: GENERA, SPECIES, REFERENCES. (http://researcharchive.calacademy. org/research/ichthyology/catalog/fishcatmain.asp). Electronic version accessed 11122017.

Esmaeili HR, Sayyadzadeh G, Coad BW, Eagderi S (2016) Review of the genus Garra Hamilton, 1822 in Iran with description of a new species: a morpho-molecular approach (Teleostei: Cyprinidae). Iran J Ichthyol 3(2):82-121

Fowler HW, Steinitz H (1956) Fishes from Cyprus, Iran, Iraq, Israel and Oman. Bull Res Counc Isr 5B:262-289

Freyhof J, Hamidan NA, Feulner G, Harrison I (2015) The status and distribution of freshwater fishes of the Arabian peninsula. In: García N, Harrison I, Cox N, Tognelli MF (eds) The status and distribution of freshwater biodiversity in the Arabian peninsula. IUCN, Gland, pp 16-29

Hamidan NA, Geiger MF, Freyhof J (2014) Garra jordanica, a new species from the Dead Sea basin with remarks on the relationship of G. ghorensis, G. tibanica and G. rufa (Teleostei: Cyprinidae). Ichthyol Explor Freshwaters 25:193-288

Hammer $\varnothing$, DAT H, Ryan PD (2001) PAST: Paleontological Statistics Software Package for Education and Data Analysis. Palaeontol Electron 4(1):9

Kirchner S, Sattmann H, Haring E, Plan L, Victor R, Kruckenhauser L (2017) Investigating gene flow between the blind cavefish Garra barreimiae and its conspecific surface populations. Sci Rep 7(5130). https://doi. org/10.1038/s41598-017-05194-3
Kruckenhauser L, Haring E, Seemann R, Sattmann H (2011) Genetic differentiation between cave and surface- dwelling populations of Garra barreimiae (Cyprinidae) in Oman. BMC Evol Biol 11(172). https://doi.org/10.1186/14712148-11-172

Krupp F (1983) Freshwater fishes of Saudi Arabia and adjacent regions of the Arabian peninsula. In: Fauna of Saudi Arabia. Basel, Jeddah, pp 568-636

Krupp F (1988) Freshwater fishes of the Wadi Batha drainage. J Oman Stud 401-404

Krupp F, Budd K (2009) A new species of the genus Garra (Teleostei: Cyprinidae) from Oman. Aqua 15(2):117-120

Lundberg JG, Marsh E (1976) Evolution and functional anatomy of the pectoral fin rays in cyprinoid fishes, with emphasis on the suckers (family Catostomidae). Am Midl Nat 96:332349

Lyon RG, Geiger MF, Freyhof J (2016) Garra sindhi, a new species from the Jebel Samhan nature Reserve in Oman (Teleostei: Cyprinidae). Zootaxa 4154:79-88. https://doi. org/10.11646/zootaxa.4154.1.5

Menon A (1964) Monograph of the cyprinid fishes of the genus Garra Hamilton. Mem Indian Museum 14:173-260

Mousavi-Sabet H, Eagderi S (2016) Garra lorestanensis, a new cave fish from the Tigris River drainage with remarks on the subterranean fishes in Iran (Teleostei: Cyprinidae). FishTaxa $1: 45-54$

Mousavi-Sabet H, Vatandoust S, Fatemi Y, Eagderi S (2016) Tashan cave a new cave fish locality for Iran; and Garra tashanensis, a new blind species from the Tigris River drainage (Teleostei: Cyprinidae). FishTaxa 1(3):133-148

R Development Core Team (2015) R: A Language and Environment for Statistical Computing. R Foundation for Statistical Computing, Vienna.

Sayyadzadeh G, Esmaeili HR, Freyhof J (2015) Garra mondica, a new species from the Mond River drainage with remarks on the genus Garra from the Persian Gulf basin in Iran (Teleostei: Cyprinidae). Zootaxa 4048:75-89. https://doi. org/10.11646/zootaxa.4048.1.4

Schindelin J, Arganda-Carreras I, Frise E, Kaynig V, Longair M, Pietzsch T, Preibisch S, Rueden C, Saalfeld S, Schmid B, Tinevez JY, White DJ, Hartenstein V, Eliceiri K, Tomancak P, Cardona A (2012) Fiji: an open-source platform for biological-image analysis. Nat Methods 9(7):676-682

Schlick-Steiner BC, Steiner FM, Seifert B, Stauffer C, Christian E, Crozier RH (2010) Integrative taxonomy: a multisource approach to exploring biodiversity. Annu Rev Entomol 55: 421-438. https://doi.org/10.1146/annurev-ento-112408085432

Stiassny MLJ, Getahun A (2007) An overview of labeonin relationships and the phylogenetic placement of the afroAsian genus Garra Hamilton, 1922 (Teleostei: Cyprinidae), with the description of five new species of Garra from Ethiopia, and a key to all African species. Zool J Linnean Soc 150:41-83

Wickham H (2009) ggplot2: Elegant Graphics for Data Analysis. Springer-Verlag, New York

Yang L, Mayden RL (2010) Phylogenetic relationships, subdivision, and biogeography of the cyprinid tribe Labeonini (sensu Rainboth, 1991) (Teleostei: Cypriniformes), with comments on the implications of lips and associated structures in the labeonin classification. Mol Phylogenet Evol 54:254-265 